\title{
Stakeholder Insight on Corporate Social Responsibility Model Implementation in Indian Organizations: Some Key Issues
}

\author{
Sunita Pachar
}

\begin{abstract}
Corporate Social Responsibility is a very important part of business worldwide. It basically includes social responsibilities of stakeholders. Different organizations implements CSR practices according to their aptness rather than the necessities of society. Hence, it becomes very important to investigate the stakeholder's perception about CSR implementation in Indian organizations. Thus, this study examines perception of stakeholders towards CSR strategy .Main purpose of this research paper was to develop a user friendly \& rationale CSR model for Indian organizations. From the literature review, a few areas were identified as social, ethical, economical and environmental responsibility and responsibility towards stakeholders. The study is based on primary data. The study shows that demographic variables do not have much influence on results .Results shows that stakeholder want organization should focus on environment sustainability on utmost priority rather than economical issues. Moreover, the paper finding suggests that organisations should implement CSR Strategy based on CSR model approach for betterment of its stakeholders [1],[3],[5]

Research implications -This research work can be helpful in the development of CSR model in Indian organizations.
\end{abstract}

Index terms: Community, Economic performance, Stakeholder and Socially responsible organization.

\section{INTRODUCTION}

The conception of Corporate Social Responsibility in India has been followed since ancient times although informally. All organizations depend on society directly or indirectly and they have an impact all the way through their operations and through their interaction with stakeholders. Bowen's (1953) was the first researcher in academics who writes on CSR.He discussed all the responsibilities of a businessman which is essential for sustainability .He focused on business social responsibility that business always should respect Value \& culture of society in which it exist. Different Studies have shown that every country have its own CSR policy and their framework [1]. These might be due to differences in rules and regulations and different culture orientation. Carroll (1991; 1999) had given a four-part definition of CSR: economic, legal, ethical and philanthropic. In today's era, stakeholders are attentative and business has to fulfill all stakeholders' demand.Busniess has to disclose its sustainability report .If business fails to fulfill its CSR responsibilities it can have an effect on reputation of business .Research shows that firms which are socially responsible can do better than their competitors [2]. Transparency and accountability are now day's very important factors and organizations have pressure from Govt. \& shareholders to implement CSR practices in their business.

Hence, it becomes very important to investigate the stakeholder's perception about CSR implementation in Indian organizations. CSR has considerable influence on Stakeholders performance [3]. Studies show that CSR and financial performance have a positive correlation and both business and stakeholders have an effect on each other [4]. Stakeholders have an influential power, which can inflate the business so business always should take-care interest of its stakeholders and always should disclose its social activities or sustainability report to its stakeholders [5]. Employees are more satisfied in those organizations which are implementing CSR practices and focusing on better facilities for employees [6]. Employees are more committed in socially responsible organizations. CSR performs an important role in employee's decision making about any organization's work culture or higher authority.CSR has considerable influence on stakeholder in a wide range of ways and has a positive effect on corporate performance [7].

Some studies also found that demographic factors had some influence on perception of CSR concept; there has been a significant difference of CSR perception between male and female [8]. Some Previous studies also found that the younger respondents had a more positive perception toward CSR.This study will also be helpful to add some inputs in literature by including the gender, marital status, age and profession as one of the important demographic factors.

II RESEARCH GAP

It can be seen from the review of literature that a few studies have been done in India regarding CSR practices. But none of the studies mentioned that in CSR issues to which issue company should give priority, which dimension should be given priority by company or whether company should give equal importance to all CSR issues in their organization. Thus, this study attempts to identify the perception of stakeholder's that to which issues Company should give priority regarding CSR implementation practices [3], [7]. 


\section{OBJECTIVE OF THE STUDY}

This study main purpose is to develop a user friendly model for Indian Organizations. Stakeholder's perception has been taken to develop CSR model.

1. To know the stakeholders perception about CSR Model

2. To know the demographic factors impact on CSR dimension

3. To Suggest workable measures for improvements in CSR implementation in India

\section{Hypothesis of the study}

H0 (1) : no significant difference between male and female respondents regarding CSR Practices variables as : economic ,social, ethical , philanthropic , employees, consumers, investors, community and environment.

H0 (2): no significant difference between age wise respondents regarding CSR Practices variables as: economic, social, ethical, philanthropic, employees, consumers, investors, community and environment.

H0 (3): no significant difference between profession wise as service, business and unemployed respondents regarding CSR Practices variables as : economic ,social, ethical, philanthropic, employees, consumers, investors, community and environment.

\section{RESEARCH METHODOLOGY}

\section{Questionnaire Design and Data Collection}

For this study, primary data have been collected from 300 stakeholders i.e. Shareholder, Customer, Company employee and Community or other stakeholder to identify the various factors responsible for CSR practices in Indian organization.

Scale of CSR Cognition.- the scale for CSR is used given by Carroll which includes four responsibilities which is expected from Indian organizations are respectively as economic, legal, ethical and philanthropic responsibilities [9].Responsibilities towards different stakeholders are respectively as employees ,consumers, investors, communities and environment [10]. This section deals with interpretation of results of all CSR practices dimensions importance and their applicability in Indian organizations with respect to demographic variables.Cronbach's alpha coefficients of the data were found above. 7 which had indicated good internal consistency.

\section{RESULT \& DISCUSSION}

\section{Conceptualization}

In conceptualizing the study (Figure 1), we have attempted to build relationship between key variables of CSR practices (Environmental, ethical, legal, social and philanthropic) (independent variables) and Stakeholders perception (dependent variable).

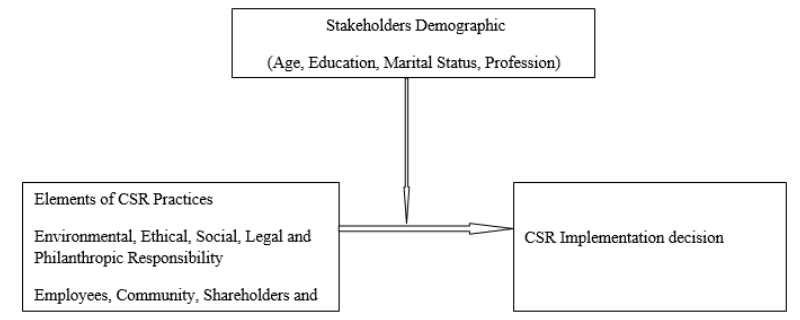

Figure 1: Conceptual Model of CSR

\section{CSR MODEL FOR INDIAN ORGANIZATIONS}

Indian stakeholder's wants organization should give priority to Environmental issues followed by responsibility towards stakeholders and social, ethical or economical accountability. In environmental dimension organization should give priority to preserving the resources, air pollution and water pollution issues etc.In stakeholders' organization should give their priority to employees followed by community, customer and shareholders. According to responsibility or accountability Indian stakeholder's wants that organization should give priority to ethical issues followed by, philanthropic, legal and economic. It seems that Indian stakeholders are more concerned with Environmental issues and majority of the respondent wants that Indian Organizations should take care of Environmental issues. Organization should apply high quality standards for disclosure of environmental reporting.

\section{IMPACT OF DEMOGRAPHIC FEATURES ON THE CSR MODEL}

Table 1: Gender wise analysis of CSR Practices

\begin{tabular}{|c|c|c|c|c|c|c|}
\hline \multirow{2}{*}{$\begin{array}{l}\text { Dimension of } \\
\text { CSR }\end{array}$} & \multicolumn{2}{|c|}{ Male $=155$} & \multicolumn{2}{|c|}{ Female $=145$} & \multirow[t]{2}{*}{ T - value } & \multirow{2}{*}{$\begin{array}{l}\text { Significant } \\
\text { value }\end{array}$} \\
\hline & Mean & S.D. & Mean & S.D. & & \\
\hline Economic (F1) & 3.35 & .60 & 3.40 & .63 & .746 & $.388=\mathrm{NS}$ \\
\hline Legal (F2) & 3.62 & .72 & 3.77 & .65 & .052 & $.820=\mathrm{NS}$ \\
\hline Ethical (F3) & 3.75 & .93 & 3.75 & .66 & 1.769 & $.185=\mathrm{NS}$ \\
\hline Philanthropic (F4) & 3.70 & .85 & 3.71 & .84 & .047 & $.828=\mathrm{NS}$ \\
\hline Employees (F5) & 3.87 & .69 & 3.85 & .61 & .287 & $.593=\mathrm{NS}$ \\
\hline Consumers (F6) & 3.70 & .73 & 3.75 & .65 & 1.657 & $.199=\mathrm{NS}$ \\
\hline Investors (F7) & 3.47 & .83 & 3.54 & .71 & 1.929 & $.166=\mathrm{NS}$ \\
\hline Communities (F8) & 3.79 & .75 & 3.84 & .74 & .775 & $.379=\mathrm{NS}$ \\
\hline Environment (F9) & 3.99 & .77 & 3.98 & .68 & .625 & $.430=\mathrm{NS}$ \\
\hline
\end{tabular}

NS= Not Significant Source: Field Survey

From table 1 it can be interpreted that the mean score on different dimension of CSR Practices in Indian Organization is highest on Environment Dimension as Male respondents mean score is (3.99) \& Female respondents mean score is (3.98). The lowest mean score is on Economic Dimension for both Male \& Female respondents as (3.35) and (3.40). Thus it can be said that Male \& Female respondents thinks that Companies should give more focus on Environment issues .Organization should least focus on Economical issues .Furthermore, the T-value is not significant at .05 level of significance. 
Therefore the null hypothesis is accepted and hence concluded that both male $\&$ female respondents have more or less same opinion about CSR Practices in Indian Organizations.

Table 2: Age wise analysis of CSR practices

\begin{tabular}{|c|c|c|c|c|c|c|c|c|c|c|}
\hline \multirow{2}{*}{$\begin{array}{l}\text { Dimension of } \\
\text { CSR }\end{array}$} & \multicolumn{2}{|l|}{$\overline{A l}=124$} & \multicolumn{2}{|c|}{$\mathrm{A} 2=109$} & \multicolumn{2}{|l|}{$A 3=53$} & \multicolumn{2}{|c|}{$\overline{A A}=14$} & \multirow{2}{*}{$\begin{array}{l}\text { F- } \\
\text { value }\end{array}$} & \multirow{2}{*}{$\begin{array}{l}\text { Significant } \\
\text { value }\end{array}$} \\
\hline & Mean & S.D. & Mean & S.D. & Mean & S.D. & Mean & S.D. & & \\
\hline Economic (F1) & 3.32 & .63 & 3.42 & .58 & 3.37 & .60 & 3.47 & .76 & .613 & $.607=\mathrm{NS}$ \\
\hline Legal (F2) & 3.66 & .75 & 3.64 & .62 & 3.85 & .61 & 3.80 & .88 & 1.300 & $.275=\mathrm{NS}$ \\
\hline Ethical (F3) & 3.61 & .76 & 3.82 & .93 & 3.91 & .62 & 3.85 & .86 & 2.238 & $.084=\mathrm{NS}$ \\
\hline $\begin{array}{l}\text { Philanthropic } \\
\text { (F4) }\end{array}$ & 3.63 & .84 & 3.68 & .85 & 3.99 & .74 & 3.48 & .97 & 2.651 & $.049^{\circ}$ \\
\hline Employees (F5) & 3.75 & .70 & 3.95 & .64 & 3.95 & .51 & 3.84 & .69 & 2.229 & $.085=\mathrm{NS}$ \\
\hline Consumers (F6) & 3.63 & .77 & 3.81 & .63 & 3.79 & .64 & 3.65 & .51 & 1.548 & $.202=\mathrm{NS}$ \\
\hline Investors (F7) & 3.41 & .76 & 3.51 & .81 & 3.67 & .77 & 3.66 & .58 & 1.661 & $.175=\mathrm{NS}$ \\
\hline $\begin{array}{l}\text { Communities } \\
\text { (F8) }\end{array}$ & 3.70 & .79 & 3.87 & .70 & 3.88 & .70 & 4.08 & .68 & 1.884 & $.132=\mathrm{NS}$ \\
\hline $\begin{array}{l}\text { Environment } \\
\text { (F9) }\end{array}$ & 3.92 & .79 & 3.99 & .69 & 4.12 & .67 & 4.05 & 46 & .997 & $.394=\mathrm{NS}$ \\
\hline
\end{tabular}

*Significant at 0.05 levels, NS=Not Significant, Source:

\section{Field Survey}

\section{Age Wise}

Result from Table 2 shows that the comparison of CSR Dimension between different age wise respondent differ significantly on one Dimension of CSR practices as "Philanthropic Dimension". As the mean values for the above age category respectively as $(3.63,3.68,3.99$ and 3.48) which shows that there is significant difference between all age categories groups at .05 levels of significance regarding Philanthropic Dimension. Therefore the null hypothesis "There is no significant difference between age wise respondents regarding CSR Practices variable philanthropic " is rejected .Furthermore It can be concluded that F-values are not significant for Economic , Legal , Ethical ,Company employees , Customer , investor , Community and Environment at .05 level of significance .Thus the null hypothesis "There is no significant difference between age wise respondents regarding CSR Practices variables as : economic ,social, ethical, employees, consumers, investors , community and environment" is accepted and it can be said that except Philanthropic Dimension all respondents education wise have same opinion regarding CSR dimensions.

Table 3: Profession wise analyses of CSR practices

\begin{tabular}{|c|c|c|c|c|c|c|c|c|c|c|}
\hline \multirow[t]{2}{*}{$\begin{array}{ll}\text { Dimension } & \text { of } \\
\text { CSR } & \end{array}$} & \multicolumn{2}{|c|}{\begin{tabular}{|l|} 
Company \\
employee $=75$
\end{tabular}} & \multicolumn{2}{|c|}{ Customer $=75$} & \multicolumn{2}{|c|}{ Shareholder $=75$} & \multicolumn{2}{|c|}{$\begin{array}{l}\begin{array}{l}\text { Community or } \\
\text { other } \\
\text { stakeholder }=75\end{array}\end{array}$} & \multirow[t]{2}{*}{$\begin{array}{ll}F \\
\text { value }\end{array}$} & \multirow[t]{2}{*}{$\begin{array}{l}\text { Significant } \\
\text { value }\end{array}$} \\
\hline & Mean & S.D. & Mean & S.D. & Mean & S.D. & Mean & S.D. & & \\
\hline Economic (F1) & 3.34 & .62 & 3.30 & .56 & 3.58 & .60 & 3.28 & .65 & 3.856 & $.010^{* *}$ \\
\hline Legal (F2) & 3.62 & .80 & 3.66 & .56 & 3.74 & .69 & 3.75 & 69 & .675 & $.568=\mathrm{NS}$ \\
\hline Ethical (F3) & 3.69 & .81 & 3.72 & .68 & 3.96 & 1.01 & 3.63 & .68 & $2.398 \mathrm{~S}$ & $.068=\mathrm{NS}$ \\
\hline Philanthropic (F4) & 3.64 & .87 & 3.66 & .77 & 3.95 & .76 & 3.58 & .92 & 2.930 & $.034^{\circ}$ \\
\hline Employees (F5) & 3.86 & .74 & 3.85 & .54 & 3.89 & .59 & 3.83 & .73 & .114 & $.952=\mathbb{N S}$ \\
\hline Consumers (F6) & 3.67 & .76 & 3.66 & .68 & 3.77 & .69 & 3.80 & .64 & .747 & $.525=\mathrm{NS}$ \\
\hline Investors (F7) & 3.50 & .77 & 3.39 & .77 & 3.62 & .78 & 3.51 & .78 & $1.172 \mathrm{~s}$ & $.321=N S$ \\
\hline Communities (F8) & 3.76 & .74 & 3.75 & .74 & 3.90 & .74 & 3.85 & .76 & .671 & $.570=\mathrm{NS}$ \\
\hline Environment (F9) & 3.96 & .81 & 4.00 & .70 & 4.02 & .65 & 3.98 & .74 & .091 & $.965=\mathrm{NS}$ \\
\hline
\end{tabular}

*Significant at 0.05 levels, ** Significant at .01 level Sources: Field Survey
Result from table No.-3 shows that the Comparison of CSR Practices between Profession wise analysis differ significantly at .05 and .01 level of significance on two Dimension of CSR practices . Therefore it can be concluded that there is significant difference between Profession wise respondents regarding F1(Economic Dimension) and F4 (Philanthropic Dimension).Respondents have different -2 opinion regarding these two Dimensions .Other seven Dimensions are not significant at .05 level of significance. It means that on Legal, Ethical, Employees, Consumers, Investors, Communities and Environments factors people have the same opinion.

As Profession wise analysis shows that for the companies most important Dimension should be Environment, companies should take care of Environment on priority basis as its means score is highest for all stakeholder group as company employees, customer ,shareholder ,community or other stakeholder i.e. (3.96, 4.00, 4.02 and 3.98). Organization should least focus on Economic dimension as its mean score is lowest for all stakeholder groups i.e. company employees, customer, shareholder, community or other stakeholder i.e. (3.34, 3.30, 3.58 and 3.58).

\section{RECOMMENDATION}

The study provides some basic inputs about CSR implementation in Indian organizations as environment sustainability issues are main concern in today's world.

1. All Indian organizations should make a clear CSR policy and they should integrate social ,ethical and environmental responsibility into their core organisational strategies [9].

2. Organizations should develop relationship with all stakeholder groups and satisfy each stakeholder [10].

3. Organization should disclose their CSR activities and must publish sustainability report $[5,12]$.

4. Companies should focus their CSR activities in those areas where improvements and upliftments of social issues are required [11].

\section{CONCLUSION}

CSR practices are very essential for every country in overall development. Government alone cannot do sustainable development and overall growth of the country .Indian corporate has resources and strategic planning to facilitate extensive social change. Stakeholders are also nowadays more concerned about social issues and they consider it on top priority for any organization to implement. Effective public-private partnerships and role of NGO in less privileged areas can improve in social development and rural areas. 


\section{REFERENCES}

1. Maignan, I. and Ferrell, O. C., Nature of Corporate Responsibilities: Perspective from American, French and German Consumers, 2003, Journal of Business Research, V- 8, P-55-67.

2. Silberhorn and Warren, Defining Corporate Social Responsibility: A view from big companies in Germany and the UK, 2007, European Business Review, V-19, 5, P-352-377.

3. Markowitz, Choosing Socially Responsible Stocks, 1972, Business and Society Review- 1, P- 71-75.

4. Carroll, A. B., the Pyramid of Corporate Social Responsibility Toward the Moral Management of Organizational Stakeholders, 1991, Business Horizons, V-34, 4, P-39-48.

5. Roberts, Determinants of Corporate Social Responsibility Disclosures: An Application of Stakeholder Theory, 1992, Accounting Organizations and Society, V-17, 6, P-592-612.

6. Greening \& Turban, Corporate Social Responsibility as a Participative Process. Business Ethics, 2000, A European Review, V-8, 1, P-43-49.

7. Aguilera, putting the back in Corporate Social Responsibility: a Multilevel Theory of Social Change in Organizations, 2007, Academy of Management Review, V-32, 3, P-836-863.

8. Maignan, I. and Ferrell, O. C., Nature of Corporate Responsibilities: Perspective from American, French and German Consumers, 2003, Journal of Business Research, Vol.56, p 55-67.

9. Carroll, A.B., A Three-Dimensional Conceptual Model of Corporate Performance, 1979, Academy of Management Review, V-4, 4, p-497.

10. Clarkson, A Stakeholder Framework for Analyzing and Evaluating Corporate Social Performance, 1995, Academy of Management Review- 20,1,P- 98-103.

11. Gautam R. \& Singh A., Corporate Social Responsibility Practices in India: A Study of Top 500 Companies, 2010, Global Business and Management Research: An International Journal, V- 2, 1, p 41-56.

12. Roberts, R.W., Determinants of Corporate Social Responsibility Disclosures: An Application of Stakeholder Theory, 1992, Accounting Organizations and Society- 17 ,6, P- 599-603.

\section{AUTHORS PROFILE}

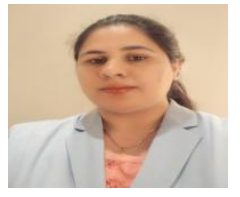

An academician having 12 years of experience in teaching and research and presently working as Assistant professor at GLA University, Mathura in IBM Department. She is actively involved in research and publication. She has published 15 research papers in national or International reputed journal. She has presented more than 25 research paper in national or international conferences. Her interest area is HR, Organizational behavior, Corporate Social Responsibility and Marketing. 